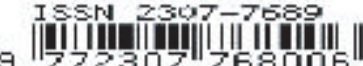

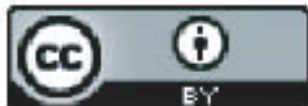

Online

$3 N 2015-6054$ ||⿴囗十)

Mediscope

ORIGINAL ARTICLE

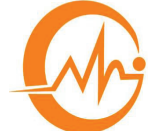

The Journal of GMC

\title{
Antibacterial effect of Ginger (Zingiber officinale) against Staphylococcus aureus
}

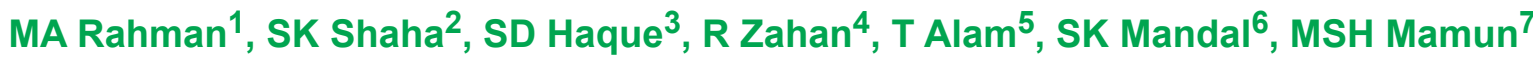

\begin{abstract}
This experimental study was carried out to determine the antibacterial effect of Crude Ginger Extract (CGE) and Ethanolic Ginger Extract (EGE) against standard strain of Staphylococcus aureus in the Department of Pharmacology and Therapeutics with the collaboration of Department of Microbiology, Mymensingh Medical College, Mymensingh from July 2016 to June 2017. The growth of Staphylococcus aureus started to be inhibited from $70 \%$ CGE incorporated media and complete inhibition of growth occurred at $100 \%$ CGE. In case of Ethanolic Extract, sensitivity was seen against Staphylococcus aureus using disc diffusion method. Zones of inhibition were 8, 13 and $19 \mathrm{~mm}$ at 25, 50 and $100 \mu \mathrm{g} / 10 \mu \mathrm{l}$ respectively. The minimum inhibitory concentration (MIC) of EGE was assessed by broth dilution technique. The MIC of EGE was $400 \mu \mathrm{g} / \mathrm{ml}$ against Staphylococcus aureus. From the study it is clearly observed that there is definite antibacterial effect of crude ginger extract (CGE) and ethanolic ginger extract against Staphylococcus aureus. Further studies are required to detect and isolate the active ingredients present in the Ginger extract responsible for antibacterial effect.
\end{abstract}

\section{Introduction}

Medicinal plants are found to be useful as pharmaceuticals, nutraceuticals, cosmetics and food supplements. ${ }^{1}$ Plant derived products have been used for medicinal purposes for centuries. In traditional Indian medicine or Ayurveda, Zingiber officinale and many other herbs have been used as medicine. ${ }^{2}$ With an increase in the antibiotic-resistant strains of microorganisms, traditional plants are being investigated for their antibacterial and medicinal values. Traditional uses of plants have led to investigating their bioactive compounds, which have resulted in the detection of a significant number of therapeutic properties. ${ }^{1}$ Ginger has been used as medicine from Vedic period and is called 'maha- aushadhi' which means the great medicine. ${ }^{2}$ Ginger is easily available, universally acceptable and relatively inexpensive and well tolerated by

1. Dr. Md. Abdur Rahman, MBBS, M. Phil, Assistant Professor and Head, Department of Pharmacology and Therapeutics, Ad-din Akij Medical college, Khulna. Mobile no: 01714849686, Email: dr.rana3939@gmail.com

2. Prof. Dr. Shyamal Kumar Shaha, MBBS, M. Phil, Prof. and Head, Dept of Pharmacology and Therapeutics, Mymensingh Medical College, Mymensingh

3. Dr. Syed Didarul Haque, MBBS, M. Phil, Assistant Professor, Department of Pharmacology and Therapeutics, Gazi Medical College, Khulna

4. Dr. Refat Zahan, MBBS, MPH, Assistant Professor and Head, Department of Community Medicine, Ad-din Akij Medical College, Khulna

5. Dr. Tarifat Alam, MBBS, M. Phil, Assistant Professor, Department of Pharmacology and Therapeutics, Ad-din Akij Medical College, Khulna

6. Dr. Subir Kumar Mandal, MBBS, M. Phil, Assistant Professor, Department of Biochemistry, Ad-din Akij Medical College, Khulna

7. Dr. Md. Shamsul Huda Mamun, MBBS, DFM, Assistant Professor, Department of Forensic Medicine, Ad-din Akij Medical College, Khulna 
most of the people. The ginger has been listed in'Generally Recognized as Safe' (GRAS) document of the US FDA. ${ }^{2}$ Ginger (Zingiber officinale) belongs to Zingiberaceae family.1 The Zingiberaceae plants are characterized by their tuberous or non-tuberous rhizomes, which have strong aromatic and medicinal properties. ${ }^{3}$ The active ingredients of ginger are, phenolic compounds: shogaols and gingerols; Sesquiterpenes: bisapolene, zingiberene, sesquiphellandrene, curcurmene; others: 6-dehydrogingerdione, galanolactone, gingesulfonic acid, zingerone, geraniol, ginger glycolipids. ${ }^{4}$ The active ingredients in ginger are thought to reside in its volatile oils, which comprise approximately $1-3 \%$ of its weight. ${ }^{5}$ Ginger's active ingredients have a variety of physiologic effects. For example, the gingerols have antioxidant, antiinflammatory, anti-tumor, analgesic, sedative, antipyretic and antibacterial effects in vitro and in animals. ${ }^{6,7}$ Active constituents of ginger inhibit multiplication of bacteria by membrane disruption. ${ }^{8}$ Ginger is a strong antibacterial agent against Staphylococcus aureus. ${ }^{6}$ Because of the increasing resistance of bacteria to antibiotics, herbal products are looking for new leads to develop better antibiotics. 9 Therefore the aims of this study are to investigate the antibacterial effectiveness of crude paste and ethanolic ginger extract.

\section{Materials and methods}

This experimental study was carried out in the Department of Pharmacology and Therapeutics in collaboration with the Department of Microbiology, Mymensingh Medical College, Mymensingh, during the period from July 2016 to June 2017. Ginger was used as the main material for experiment which was collected from local market of Mymensingh, Bangladesh. Another important material Aminoglycoside antibiotic (Injectable form) was bought from local market.Standard reference strains of Staphylococcus aureus ATCC 25923 was collected from Microbiology Department of Mymensingh Medical College.

\section{Preparation of crude ginger extract:}

Ginger (1000 gm) was washed initially by distilled water and then by $95 \%$ ethanol and homogenized by using sterile mortar and pestle. Then it was sieved through double layer of sterile fine mesh cloth to make crude extract. This CGE was considered as $100 \%$ crude ginger extract.

Table 01: Composition of different concentrations of CGE incorporated into Nutrient agar (NA) media

\begin{tabular}{l|c|c|c|c|}
\hline Set No. & $\begin{array}{c}\text { CGE } \\
(\mathbf{m l})\end{array}$ & $\begin{array}{c}\text { Distilled water in NA } \\
\text { media to make 100 ml }\end{array}$ & $\begin{array}{c}\text { Percentage of CGE } \\
\text { incorporated into NA media }\end{array}$ & $\begin{array}{c}\text { Test } \\
\text { organism }\end{array}$ \\
\hline Set-I & 5 & 95 & 5 & One loopful \\
\hline Set-II & 10 & 90 & 10 & One loopful \\
\hline Set-III & 15 & 85 & 15 & One loopful \\
\hline Set-IV & 20 & 80 & 20 & One loopful \\
\hline Set-V & 30 & 70 & 30 & One loopful \\
\hline Set-VI & 40 & 60 & 40 & One loopful \\
\hline Set-VII & 50 & 50 & 50 & One loopful \\
\hline Set-VIII & 60 & 40 & 60 & One loopful \\
\hline Set-IX & 70 & 30 & 70 & One loopful \\
\hline Set-X & 80 & 20 & 80 & One loopful \\
\hline Set-XI & 90 & 10 & 90 & One loopful \\
\hline Set-XII & 100 & 00 & 100 & One loopful \\
\hline Control & \multicolumn{5}{|l|}{}
\end{tabular}

* One loopful $=20 \mu \mathrm{l}$ 
Bacterial (Staphylococcus aureus) suspension was prepared by 3-5 similar colonies from 18-24 hours old agar plates and mixed with normal saline. The turbidity of the suspension was adjusted with $0.5 \mathrm{McF}$ arland standards $(1.5 \times 108$ organisms $/ \mathrm{ml})$. A cotton swab was dipped in the bacterial suspension and inoculated into CGE containing NA media as well as control plates. Then all the plates were placed in the incubator at $37 \mathrm{OC}$ for 24 hours.

\section{Preparation of ethanolic ginger extract:}

Ethanolic Ginger Extract was prepared by using 10 grams of the grounded ginger mixed with $200 \mathrm{ml}$ of $95 \%$ ethanol and left in room temperature for 24 hours. After that it was filtered by using gauze pad to remove the large particle and then centrifuged at 3000 rpm for 10 minutes. Secondary filtration was done by filter paper to obtain a clear solution which was dried at $40^{\circ} \mathrm{C}$ in hot water bath and stored in the refrigerator until use. For preparation of parent solution, $1 \mathrm{gm}$ powder extract was mixed with $10 \mathrm{ml}$ ethanol. Then it was filtered by gauze pad and centrifuged at 3000 rpm for $10 \mathrm{~min}$ and again filtered by filter paper. This solution was the source of preparing different concentrations of ethanolic ginger extract. The extract was stored at $4^{\circ} \mathrm{C}$ in refrigerator.

\section{Calculation of concentration of different EGE Disc Diffusion solutions:}

Powdered ginger extract $1 \mathrm{gm}$ in $10 \mathrm{ml}$ ethanol. This solution was marked as Parent solution. $10 \mathrm{ml}$ ethanol contains $1 \mathrm{gm}=1000 \mathrm{mg}$ ethanolic ginger extract. So, $1 \mathrm{ml}$ Solution contains $100 \mathrm{mg}$ EGE. This solution was marked as Stock EGE DD (Disc Diffusion) Solution-I. Then 1:10 dilution was done of stock EGE DD solution-I by adding $9 \mathrm{ml}$ of ethanol.

So, $10 \mathrm{ml}$ solution contains $100 \mathrm{mg}$ of EGE.So, $1 \mathrm{ml}=1000 \mu \mathrm{l}$ solution contains 10 $\mathrm{mg}=10 \times 1000 \mu \mathrm{g}$ of $E G E=10000 \mu \mathrm{g}$. Thus, 10 $\mu$ solution contained $100 \mu \mathrm{g}$ of EGE; this solution was used in Disc Diffusion Method and different lower concentration solutions ( $25 \mu \mathrm{g}$ and $50 \mu \mathrm{g}$ per $10 \mu \mathrm{l}$ ) were made from this by adding ethanol. In case of making higher concentration of disc Diffusion solution same procedure was applied but the difference was done in making Parent solution. Instead of $1 \mathrm{gm}$ of powdered ginger extract in higher concentration Disc Diffusion Solution, $2 \mathrm{gm}, 4 \mathrm{gm}$, and $8 \mathrm{gm}$ powdered ginger extract was mixed with $10 \mathrm{ml}$ ethanol. So the concentrations were $200 \mu \mathrm{g}, 400 \mu \mathrm{g}$ and 800 $\mu \mathrm{g}$ per $10 \mu \mathrm{l}$ respectively.

\section{Antibacterial sensitivity test by disc diffu- sion method:}

Antibacterial sensitivity test was performed by Modified Kirby-Bauer disc diffusion technique as following. After matching with $0.5 \mathrm{McFar}-$ land standards, a sterile cotton swab was dipped into bacterial suspension and streaked in three directions on the surface of Mueller-Hinton agar plates and then left for 5-10 minutes in room temperature. By using sterile forceps the blank paper discs $(6 \mathrm{~mm}$ in diameter) were placed on the surface of the plates. Then with the help of micropipette $5 \mu l$ amount of different concentrations of EGE were put over the blank discs and left for five minutes. Then the plates were incubated at $37^{\circ} \mathrm{C}$ for 24 hours. After that zone of inhibition for respective organisms were measured in $\mathrm{mm}$ by using ruler.

Determination of Minimum Inhibitory Concentration (MIC) of Ethanolic Ginger Extract (EGE) by broth dilution technique:

The minimum inhibitory concentration (MIC) is the concentration giving the least inhibitory activity and below which there is no further inhibition.

Stock EGE was prepared by mixing $1 \mathrm{gm}$ of powdered ginger extract in $10 \mathrm{ml}$ ethanol. 
(Parent Solution) So, $1 \mathrm{ml}$ Solution contains $100 \mathrm{mg}$ EGE. This solution was marked as Stock EGE Solution-I. To prepare more diluted working solution, 1:100 dilution was done of the stock EGE solution -I by adding $99 \mathrm{ml}$ of Ethanol.

So, $100 \mathrm{ml}$ of working solution contains 100 mg of EGE.
So, $1 \mathrm{ml}$ of working solution contains $1 \mathrm{mg}$ of EGE, This solution was marked as EGE Solution-II. This solution (EGE Solution-II) was used for determination of MIC of EGE by making different working solution of different concentrations. (Table 02)

Table 02:Composition and different concentrations of working EGE solutions with controls

\begin{tabular}{l|c|c|c|c|c|}
\hline No of Sets & $\begin{array}{c}\text { EGE } \\
\text { solution-II }(\mathbf{m l})\end{array}$ & $\begin{array}{c}\text { Nutrient broth } \\
\text { medium }(\mathbf{m l})\end{array}$ & $\begin{array}{c}\text { Total } \\
(\mathbf{m l})\end{array}$ & $\begin{array}{c}\text { Concentration } \\
\text { of EGE }(\boldsymbol{\mu g} / \mathbf{m l})\end{array}$ & $\begin{array}{c}\text { Test } \\
\text { organism }(\boldsymbol{\mu l})\end{array}$ \\
\hline Set- I & 9 & 1 & 10 & 900 & 20 \\
\hline Set- II & 8 & 2 & 10 & 800 & 20 \\
\hline Set- III & 7 & 3 & 10 & 700 & 20 \\
\hline Set- IV & 6 & 4 & 10 & 600 & 20 \\
\hline Set- V & 5 & 5 & 10 & 500 & 20 \\
\hline Set- VI & 4 & 6 & 10 & 400 & 20 \\
\hline Set- VII & 3 & 7 & 10 & 300 & 20 \\
\hline Set-VIII & 2 & 8 & 10 & 200 & 20 \\
\hline Set-IX & 1 & 9 & 10 & 100 & 20 \\
\hline Set- X C-1 & 10 & 0 & 10 & 1000 & 20 \\
\hline Set- XI C-2 & - & 10 & 10 & - & 20 \\
\hline Set-XII C-3 & - & 10 & 10 & - & - \\
\hline
\end{tabular}

With each $10 \mathrm{ml}$ preparation except control-3 (set XII) $20 \mu \mathrm{l}$ bacterial suspension was added after matching its opacity with that of 0.5 McFarland Standard. After matching the turbidity of bacterial suspension with 0.5 McFarland standards, $20 \mu$ or one drop $(0.02$ m1) of bacterial suspension of Staphylococcus aureuswas separately added with each concentrations of working EGE in separate test tubes. These inoculum was also added to the controls (I and 2) except Control-3. The test tubes were marked set wise with black marker and were placed in the incubator at 37 $0 \mathrm{C}$ for $18-24$ hours. Then growth of test organism in each preparations of EGE were examined and compared against that of controls by matching their turbidity. The clear preparations were considered as no growth of bacteria and turbid ones, as growth of bacteria. The MIC was reported as lowest concentration of EGE required to prevent the visible growth of test organism.

\section{Results}

\section{Inhibitory effects of crude ginger extract}

Table 03 shows that there was no inhibition of growth of Staphylococcus aureus from $5 \%$ to 60\% CGE incorporated medium. The growth of Staphylococcus aureus started to be inhibited from $70 \%$ CGE incorporated media and complete inhibition of growth occurred at $100 \%$. 
Table 03: Inhibitory effect of CGE incorporated into Nutrient agar medium against growth of Staphylococcus aureus

\begin{tabular}{|l|c|l|l|}
\hline \multicolumn{1}{|c|}{ No of Sets } & $\begin{array}{c}\text { Percentage of CGE } \\
\text { in NA media }\end{array}$ & $\begin{array}{c}\text { Amount of } \\
\text { inoculation }\end{array}$ & $\begin{array}{c}\text { Staphylococcus } \\
\text { aureus }\end{array}$ \\
\hline Set-I & 5 & One loopful & Growth not inhibited \\
\hline Set- II & 10 & One loopful & Growth not inhibited \\
\hline Set-III & 15 & One loopful & Growth not inhibited \\
\hline Set-IV & 20 & One loopful & Growth not inhibited \\
\hline Set-V & 30 & One loopful & Growth not inhibited \\
\hline Set- VI & 40 & One loopful & Growth not inhibited \\
\hline Set-VII & 50 & One loopful & Growth not inhibited \\
\hline Set-VIII & 60 & One loopful & Growth not inhibited \\
\hline Set-IX & 70 & One loopful & Medium growth \\
\hline Set-X & 80 & One loopful & Medium gro wth \\
\hline Set- XI & 90 & One loopful & Medium growth \\
\hline Set-XII & 100 & One loopful & No growth \\
\hline Set-XIII (Control) & Without CGE & One loopful & Huge Growth \\
\hline
\end{tabular}

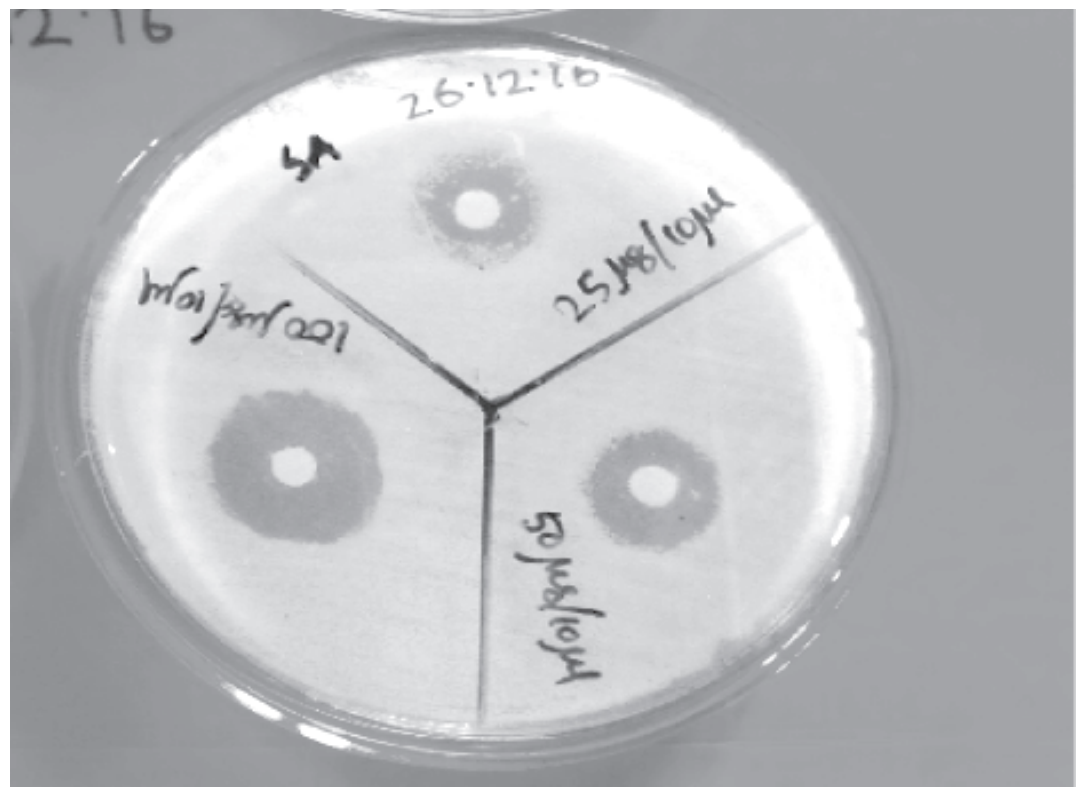

Figure 01: Disc Diffusion showing Staphylococcus aureus is sensitive to EGE.

Antibacterial sensitivity testing of ethanolic ginger extract

In case of Ethanolic extract in disc diffusion method sensitivity was seen against Staphylococcus aureus Zone of inhibition $8 \mathrm{~mm}$ at 25 $\mu \mathrm{g} / 10 \mu \mathrm{l}, 13 \mathrm{~mm}$ at $50 \mu \mathrm{g} / 10 \mu \mathrm{l}$ and $19 \mathrm{~mm}$ at $100 \mu \mathrm{g} / 10 \mu \mathrm{l}$ concentration (Figure 01).
Determination of minimum inhibitory concentration (MIC) of ethanolic ginger extract

Table 04 shows that visible growth of Staphylococcus aureus was from Set-VII to Set-IX. And no growth was visible from Set-I to Set-VI. So, the MIC of EGE against Staphylococcus aureus was $400 \mu \mathrm{g} / \mathrm{ml}$ (Set-VI). 
Table 04: MIC of EGE against Staphylococcus aureus

\begin{tabular}{l|c|c|}
\hline No. of Sets & Concentration(EGE) $(\mu \mathrm{g} / \mathrm{ml})$ & Escherichia Coli \\
\hline Set-I & 900 & No Growth \\
\hline Set-II & 800 & No Growth \\
\hline Set-III & 700 & No Growth \\
\hline Set-IV & 600 & No Growth \\
\hline Set-V & 500 & No Growth \\
\hline Set-VI & 400 & No Growth \\
\hline Set-VII & 300 & Growth \\
\hline Set-VIII & 200 & Growth \\
\hline Set-IX & 100 & Growth \\
\hline Set-X Control -1 & No & No Growth \\
\hline Set-XIControl- 2 & N/A media + Bacteria & Huge Growth \\
\hline Set-XIIControl- 3 & Nodia + No Bacteria & No Growth \\
\hline
\end{tabular}

\section{Discussion}

In this study it is found that $100 \%$ CGE has complete inhibitory effect against Staphylococcus aureus. Shah P10 also found that crude ginger extract has antibacterial activity against Staphylococcus aureus which is almost similar to this study. Karuppiah P11 determined the antibacterial effect of Allium sativum cloves and Zingiber officinale rhizomes against multi-drug resistant clinical pathogens with the help of disc diffusion method. In that study the zone of inhibition against Staphylococcus aureus was $9.30 \mathrm{~mm}$ at $25 \mu \mathrm{g} / \mathrm{ml}, 11.55 \mathrm{~mm}$ at $50 \mu \mathrm{g} / \mathrm{ml}$ and 12.52 $\mathrm{mm}$ at $100 \mu \mathrm{g} / \mathrm{ml}$. In this study it was $8 \mathrm{~mm}$ at $25 \mu \mathrm{g} / \mathrm{ml}, 13 \mu \mathrm{mm}$ at $50 \mu \mathrm{g} / \mathrm{ml}$ and $19 \mathrm{~mm}$ at $100 \mu \mathrm{g} / \mathrm{ml}$, which is almost similar with that study. Kaushik P12 determined the antibacterial effect of ginger with the help of agar well diffusion method against Staphylococcus aureus with the use of various solvents. In ethanolic extract Staphylococcus aureus was sensitive and zone of inhibition was $14 \mathrm{~mm}$. In this study Staphylococcus aureus is sensitive to ethanolic ginger extract. Neihaya HZ13, determine the antibacterial effect of ginger and black pepper extracts (alone and combination) with sesame oil on some pathogenic bacteria at different concentration. In that study zone of inhibition was $13 \mathrm{~mm}$, against Staphylococcus aureus at $10 \%$ concentration. But in this study zone of inhibition was $8 \mathrm{~mm}$ at $25 \mu \mathrm{g} / \mathrm{ml}$. In both studies Staphylococcus aureus was sensitive to ethanolic ginger extract. Karuppiah P14 determined the MIC of ethanolic ginger extract against Staphylococcus aureus was $67 \mu \mathrm{g} / \mathrm{ml}$. But in this study the MIC of EGE was against Staphylococcus aureus $400 \mu \mathrm{g} / \mathrm{ml}$. This is bit different with this study. This may be due to the species difference or the ginger difference in different biologic condition.

\section{Conclusion}

From this study it is clearly observed that there is definite antibacterial effects of ethanolic Ginger extract (EGE) against Staphylococcus aureus. The crude Ginger extract (CGE) also has its definite inhibitory effects against Staphylococcus aureus. Further studies are required to detect and isolate the active ingredients present in the Ginger extract responsible for antibacterial effect. Then their effects against the studied organism should be studied in vivo separately and their toxicity profiles should also be taken into account. Only then the Ginger extracts will fulfill the criteria for its therapeutic use. Until then ginger may be 
used in gastrointestinal tract infection, respiratory tract infection, skin infection and urinary tract infection along with the conventional antibiotics which are used in those conditions.

\section{References}

1. S wati S, Rekha V, Tribhuwan S. Evaluation of antimicrobial efficacy of some medicinal plants. Journal of chemical and Pharmaceutical

Research. 2010;2(1):121-4.

2. Islam K, Rowsni AA, Khan MM, Kabir MS. Antimicrobial activity of ginger (Zingiber officinale) extracts against food-borne pathogenic bacteria. International Journal of Science, Environment and Technology. 2014;3(3):867-71.

3. Chen IN, Chang CC, Ng CC, Wang CY, Shyu YT, Chang TL. Antioxidant and antimicrobial activity of Zingiberaceae plants in Taiwan. Plant foods for human Nutrition. 2008 Mar 1;63(1):15-20.

4. Kathi J., Kemper., MD., MPH. Ginger (zingiber officinale).The longwood herbal taskforce and the center for holistic pediatric education and research.http://www.mcp.edu/ herbal/default/.htm.1999.

5. Newall CA., Anderson LA., Phillipson JD. Herbal medicines: a guide for health-care professionals. London: Pharmaceutical Press, 1996: vol. 9: p- 296.

6. Mascolo N., Jain R., Jain SC., Capasso F. Ethnopharmacologic investigation of ginger (Zingiber officinale). J Ethnopharmacol. 1989; 27: p-129-40.

7. Connell D., Sutherland M. A re-examination of gingerol, shogaol and zingerone, the pungent principles of Ginger (Zingiber officinale Roscoe). Aust J Chem 1969; vol. 22: p-1033-43.

8. Sherifa MM., Sarba, Luluah MR., Masoudi
A., Ahmed SH. Al-Gehani AAO. AbuHarbah.Comparative laboratory study on antibacterial effects of fresh and drtginger (zingiber officinale). 2014; Vol. 8(9).

9. Chowdhury D., Jhora ST., Saha MR., Nahar N. Antimicrobial resistance pattern of common bacterial pathogens in tertiary care hospitals in Dhaka city. Bangladesh. Journal of Medical microbial. 2013; 07(02): p-13-16.

10. Shah P., Tamimi A., Nasri AN., Mamari AR. Effect of tempeture on antibiotic properties of garlic (Allium sativum) and ginger (Zingiber officinale Rosc.) African journal of biotechnology. 2012; 11(95): p-1619216195.

11. Karuppiah P., Rajaram S., Antibacterial effect of Allium sativum cloves and Zingiber officinale rhizomes against multi-drug resistant clinical pathogens. Asian pacific Journal of Tropical Biomedicine. 2012.

12. Purshotam Kaushik, Pankaj Goyal, Evaluation of various crude extracts of zingiber officinale rhizome for potential antibacterial activity: a study in vitro. Advances in microbiology, 2011, 1 , 7-12.doi:10.4236/aim.2011.11002 publishedonline December 2011(http://www.sciRP.org/journal/aim).

13. Neihaya HZ. Rasha MSA., Tahreer H. Antibacterial effect of ginger and black pepper extracts (alone and in combination) with sesame oil on some pathogenic bacteria. World journal of pharmacy and pharmaceutical sciences. 2015; 4(3): p774-784.

14. Karuppiah P., Rajaram S., Antibacterial effect of Allium sativum cloves and Zingiber officinale rhizomes against multi-drug resistant clinical pathogens. Asian pacific Journal of Tropical Biomedicine. 2012. 